\title{
Kesiapan Usaha Perjalanan Wisata Bali terhadap Asesmen Mandiri Menuju Tatanan Kehidupan Era Baru
}

\author{
Wahyuni ${ }^{1}$ \\ Universitas Pembangunan Nasional "Veteran" Jawa Timur \\ Email: wahyuni.par@upnjatim.ac.id \\ Nelsye Lumanauw ${ }^{2}$ \\ Politeknik Internasional Bali \\ E-mail: nelsye.lumanauw@pib.ac.id
}

\begin{abstract}
New era is the main focus of tourism recovery. The travel business plays an important role in the implementation of the new era to guarantee security and trust for tourists, however, there are various obstacles encountered. The purpose of this study is to determine the readiness of the travel business in Bali for selfassessment towards the new era. Qualitative descriptive analysis method is used to analyze the selfassessment towards the new era in the travel business. The selfassessment consists of 7 elements of product aspects, 3 elements of service aspects and 11 elements of management aspects, so there are 21 elements to be fullfilled. The study was conducted on six travel agencies in Bali that were still operating during the Covid-19 pandemic. The results of the study show various obstacles faced by travel businesses regarding the fulfillment of selfassessments as a form of unpreparedness for implementing the new era during the Covid-19 pandemic. Companies must take advantage of the momentum of the Covid-19 pandemic to fulfill self-assessments to ensure tourists receive quality service. Efforts to fulfill selfassessments towards a new era are the main guarantee for foreign tourists visiting the island of Bali as Indonesia's main destination.
\end{abstract}

Keywords: travel business, selfassesments, new era, pandemi Covid-19.

ABSTRAK: Tatanan kehidupan era baru menjadi tumpuan utama memulihkan pariwisata. Usaha perjalanan wisata berperan penting dalam pelaksanaan tatanan kehidupan era baru untuk memberi jaminan keamanan dan kepercayaan bagi wisatawan, namun terdapat berbagai kendala yang dihadapi. Tujuan penelitian ini untuk mengetahui kesiapan usaha perjalanan wisata Bali terhadap asesmen mandiri menuju tatanan kehidupan era baru. Metode analisis deskriptif kualitatif digunakan untuk menganalisis asesmen mandiri menuju tatanan kehidupan era baru pada usaha perjalanan wisata. Asesmen mandiri terdiri dari aspek produk 7 unsur, aspek pelayanan 3 unsur dan aspek pengelolaan 11 unsur, sehingga ada 21 unsur yang harus dipenuhi. Penelitian dilakukan terhadap enam biro perjalanan wisata di Bali yang masih beroperasi selama pandemi Covid-19. Hasil penelitian menunjukkan berbagai kendala yang dihadapi usaha perjalanan wisata terhadap pemenuhan asesmen mandiri sebagai wujud ketidaksiapan pelaksanaan tatanan kehidupan era baru di masa pandemi Covid-19. Perusahaan harus memanfaatkan momentum pandemi Covid-19 ini untuk memenuhi asesmen mandiri guna memastikan wisatawan menerima layanan yang berkualitas. Upaya pemenuhan asesmen mandiri menuju tatanan kehidupan era baru menjadi jaminan utama bagi wisatawan mancanegara mengunjungi Pulau Bali sebagai destinasi utama Indonesia.

KataKunci: usaha perjalanan wisata, asesmen mandiri, tatanan kehidupan era baru, pandemi Covid-19. 


\section{PENDAHULUAN}

Pandemi Covid-19 telah membuat berbagai lini kehidupan berubah, termasuk sektor pariwisata. Penutupan akses masuk bagi wisatawan mancanegara, sekaligus penutupan obyek daya tarik wisata telah menyebabkan terhentinya berbagai jenis usaha yang berafiliasi dengan pariwisata, seperti penyediaan akomodasi, makanan dan minuman, usaha perjalanan wisata, hingga transportasi. Penyedia penginapan mulai homestay hingga hotel berbintang, restoran, penyedia layanan transportasi wisata, usaha perjalanan wisata, hingga pekerja wisata (pramuwisata) merasakan dampak yang hebat dan perubahan dari pandemi Covid-19.

Pola berwisata kini dipengaruhi oleh kesadaran dan kepedulian terhadap kebersihan, kesehatan, keselamatan, serta kelestarian lingkungan yang tinggi. Oleh karenanya, usaha perjalanan wisata sebagai salah satu komponen dalam industri pariwisata harus bersiap diri untuk dapat memberikan jaminan kebersihan, kesehatan, keselamatan, dan kelestarian lingkungan yang tinggi terhadap produk dan pelayanan yang diberikan kepada wisatawan. Berwisata dengan protokol kesehatan yang ketat dan disiplin harus dilakukan dan disesuaikan dengan kebijakan pemerintah dan aparat setempat. Di masa menuju tatanan kehidupan era baru ini, seluruh komponen industri wisata harus bertransformasi agar lebih berkualitas dan berkelanjutan.

Usaha perjalanan wisata sebagai salah satu unsur industri pariwisata turut berperan penting dalam pelaksanaan tatanan kehidupan era baru. Lumanauw (2020:19) menyebutkan usaha perjalanan wisata menjadi penghubung antara pengguna dan penyedia jasa dengan merencanakan perjalanan wisata. Ketentuan protokol kesehatan untuk usaha perjalanan wisata, khususnya di Bali diatur dalam Peraturan Walikota Denpasar No. 48 Tahun 2020 tentang Penerapan Disiplin dan Penegakan Hukum Protokol Kesehatan Sebagai Upaya Pencegahan dan Pengendalian Corona Virus Disease 2019 dalam Tatanan Kehidupan Era Baru. Panduan operasional protokol kesehatan juga diatur dalam Keputusan Menteri Kesehatan Nomor HK.01.07/Menkes/382/2020 sebagai pedoman dalam melakukan sosialisasi dan penerapan kebersihan, kesehatan, keselamatan, dan kelestarian lingkungan demi meningkatkan keyakinan para pihak serta reputasi usaha dan destinasi pariwisata.

Sejak 31 Juli 2020, pariwisata Bali telah dibuka kembali untuk wisatawan domestik, namun keengganan masyarakat untuk melakukan perjalanan masih tinggi. Kelengkapan dokumen seperti hasil rapid test atau PCR negatif, ketidakpastian jadwal penerbangan, keraguan atas buka atau tidaknya destinasi wisata adalah beberapa alasan yang menjadi keengganan masyarakat. Hal tersebut membuat tingkat kunjungan wisatawan khususnya pasar domestik sulit didongkrak meskipun berbagai market place seperti traveloka, tiket.com dan booking.com menawarkan potongan harga cukup besar untuk hotel-hotel di Bali. Mobilitas masyarakat yang rendah selama pandemi Covid-19 memberikan dampak perlambatan peningkatan kegiatan pariwisata di Bali

Data dari Dinas Pariwisata Provinsi Bali terdapat 73 usaha perjalanan wisata yang telah melakukan verifikasi dan mendapatkan sertifikat tatanan kehidupan era baru. Jumlah ini masih relative sedikit dibandingkan dengan jumlah anggota ASITA Bali sebanyak 350 perusahaan. Tidak adanya kegiatan pariwisata, adanya pembatasan jam 
operasional dan formasi tim kerja, merupakan beberapa alasan pengelola usaha perjalanan wisata tidak mengajukan permohonan verifikasi. Ketidaksiapan usaha perjalanan wisata memenuhi persyaratan verifikasi melalui asesmen mandiri menjadi tantangan serius bagi penerapan tatanan kehidupan era baru industri pariwisata.

Pengelola usaha perjalanan wisata harus memanfaatkan momentum pandemi Covid-19 ini untuk mengevaluasi dan menata ulang layanan produk wisata menjadi lebih berkualitas dan sesuai dengan tatanan kehidupan era baru. Penerapan protokol tatanan kehidupan era baru dapat menjamin keselamatan serta keamanan wisatawan yang berkunjung dan membuat masyarakat tetap beraktivitas, sekaligus terlindungi (Gupta dan Lumanauw, 2021:86). Bagaimana kesiapan usaha perjalanan wisata dalam menyiapkan perusahaannya untuk asesmen mandiri menuju tatanan kehidupan era baru menunjukkan pentingnya penelitian ini dilakukan. Kedisiplinan dan kepatuhan terhadap tatanan kehidupan era baru oleh usaha perjalanan wisata sebagai bagian dari industri pariwisata akan mempercepat proses pemulihan pariwisata Bali sebagai barometer pariwisata Indonesia. Di samping pemulihan pariwisata, destinasi wisata Bali akan menjadi lebih berkualitas dan menjamin keamanan serta kenyamanan wisatawan.

\section{KAJIAN TEORETIK}

Usaha perjalanan wisata merupakan salah satu dari unsur industri pariwisata yang berperan penting dalam menghubungkan unsur-unsur industri wisata dengan wisatawan. Kegiatan usaha perjalanan wisata merupakan kegiatan yang bersifat komersial yang mengatur, menyediakan dan menyelenggarakan paket layanan bagi seseorang, atau sekelompok orang Bafadhal (2018:27). Tempat kerja usaha perjalanan wisata termasuk perkantoran yang disebutkan dalam Keputusan Menteri Kesehatan Republik Indonesia Nomor HK.01.07/Menkes/328/2020 tentang Panduan Pencegaharan dan Pengendalian Corona Virus Desease 2019 (Covid-19) di Tempat Kerja Perkantoran dan Industri Dalam Mendukung Keberlangsungan Usaha Pada Situasi Pandemi. Peraturan tersebut menyebutkan bahwa, diperlukan langkah-langkah untuk mencegah dan mengendalikan potensi penularan Covid-19 di lingkungan kerja yang dilaksanakan oleh seluruh komponen yang ada di tempat kerja mulai dari pekerja hingga tingkat pimpinan serta memberdayakan semua sumber daya yang ada. Berdasarkan peraturan tersebut, usaha perjalanan wisata berkewajiban melaksanakan tatanan kehidupan era baru.

Hal ini juga sesuai dengan Surat Edaran Gubernur Bali Nomor 355 Tahun 2020 tentang Protokol Tatanan Kehidupan Era Baru Sektor Pariwisata, disebutkan bahwa usaha jasa perjalanan wisata termasuk dalam sektor pariwisata yang harus melaksanakan protokol kesehatan. Usaha perjalanan wisata harus melakukan asesmen mandiri yang bertujuan untuk mengetahui gambaran kompetensi instruktur (Rahmasari, A. dkk., 2019:151), dalam pelaksanaan tatanan kehidupan baru. Asesmen mandiri untuk usaha perjalanan wisata berdasarkan Dinas Pariwisata Provinsi Bali dikategorikan menjadi dua, yaitu Memenuhi (M) dan Belum Memenuhi (BM). Tatanan kehidupan baru menurut Putra (2020) merupakan sesuatu yang tidak biasa dilakukan sebelumnya menjadi hal normal untuk dilakukan. Terkait Covid-19, new normal diartikan sebagai perubahan perilaku masyarakat yang akan mempengaruhi kegiatan sehari-hari masyarakat selanjutnya. Industri pariwisata akan mengutamakan penerapan standar protokol kesehatan dan standar 
keamanan yang dipandang memadai untuk tetap menjaga kenyaman para wisatawan berkunjung ke Bali (Paramita \& Putra, 2020:58)

Formulir asesmen mandiri diperoleh dengan mengakses aplikasi yang disediakan oleh Dinas Pariwisata Provinsi Bali atau Dinas Pariwisata Daerah Kabupaten Bali berdasarkan lokasi perusahaan. Asesmen mandiri merupakan kriteria mutlak yang terdiri dari aspek produk tujuh unsur, aspek pelayanan tiga unsur dan aspek pengelolaan 11 unsur, sehingga ada 21 unsur yang harus dipenuhi oleh usaha perjalanan wisata. Pemenuhan ketiga aspek dan 21 unsur melalui proses verifikasi dan selanjutnya memperoleh sertifikat tatanan kehidupan era baru, apabila semua unsur terpenuhi.

Berdasarkan Petunjuk Teknis Penerbitan Sertifikat Tatanan Era Baru Bidang Pariwisata dari Dinas Pariwisata Provinsi Bali, usaha pariwisata yang telah siap memenuhi standar kebersihan, kesehatan, dan keselamatan sesuai protokol tatanan kehidupan era baru bidang pariwisata akan diberikan sertifikat tatanan kehidupan era baru bidang pariwisata. Sertifikat tersebut bertujuan untuk mendapatkan pengakuan dari konsumen, memastikan aspek kebersihan, kesehatan dan keselamatan serta untuk meningkatkan daya saing dari aspek produk, pelayanan dan pengelolaan.

\section{METODE}

Penelitian ini menggunakan metode analisis deskriptif kualitatif yang berperan untuk menunjukkan seberapa jauh penelitian memiliki teori dan permasalahan yang diteliti walaupun permasalahan tersebut masih bersifat sementara (Anggito \& Setiawan, 2018:26), yang dihadapi oleh usaha perjalanan wisata dalam menghadapi tatanan kehidupan era baru. Lokasi penelitian adalah enam usaha perjalanan wisata yang masih beroperasi selama pandemi Covid-19 di Bali, yaitu Alliance Indonesia, Bali Lovindo Wisata, Ceria Tours \& Travel, Golden Kris Tours, Ravada Bali Tour dan Wahyu Mandiri. Jenis data kualitatif menguraikan tatanan kehidupan era baru oleh enamt usaha perjalanan wisata di Bali berupa berupa kriteria mutlak yang mencakup aspek dan kandungan unsur di dalamnya. Sumber data primer berupa aspek dan unsur dari kriteria mutlak diperoleh langsung dari informan yang dijumpai di kantor perusahaan atau komunikasi melalui pesan WhatsApp. Sumber data sekunder diperoleh dari publisitas berbagai instansi terkait, seperti website Badan Pusat Statistik (BPS) Provinsi Bali dan Dinas Pariwisata Provinsi Bali, guna melengkapi dan mendukung data primer yang diperoleh.

Teknik penentuan informan dilakukan berdasarkan kriteria yaitu orang yang paham mengenai protokol tatanan kehidupan era baru untuk usaha perjalanan wisata. Penelitian ini menggunakan instrumen penelitian berupa panduan wawancara. Teknik pengumpulan data melalui observasi langsung ke lokasi, wawancara informan dan dokumentasi. Tahap analisis data dilakukan secara deskriptif kualitatif terhadap asesmen mandiri yang dilakukan usaha perjalanan wisata. Hasil dari asesmen mandisi tersebut merupakan jawaban atas kesiapan usaha perjalanan wisata dalam tatanan kehidupan era baru yang merupakan rumusan masalah penelitian ini.

\section{HASIL DAN PEMBAHASAN}

Sejak dimulainya pandemi Covid-19 pada bulan Maret 2020, kondisi Bali sebagai destinasi wisata utama Indonesia menjadi terpuruk. Terjadi pembatalan besar-besaran 
atas kedatangan wisatawan mancanegara ke Bali, disertai pembatasan pergerakan sosial dan larangan bepergian atau lockdown oleh berbagai wilayah dunia. Hal ini berdampak terhadap kunjungan wisatawan mancanegara (wisman) ke Bali menurun drastis. Badan Pusat Statistik (BPS) Provinsi Bali mencatat, jumlah kedatangan wisatawan mancanegara yang datang langsung ke Bali periode satu tahun sebelum masa pandemi Covid-19, yaitu pada bulan April 2019 sampai Maret 2020 dan April 2020 sampai Maret 2021, seperti tampak pada Gambar 1.

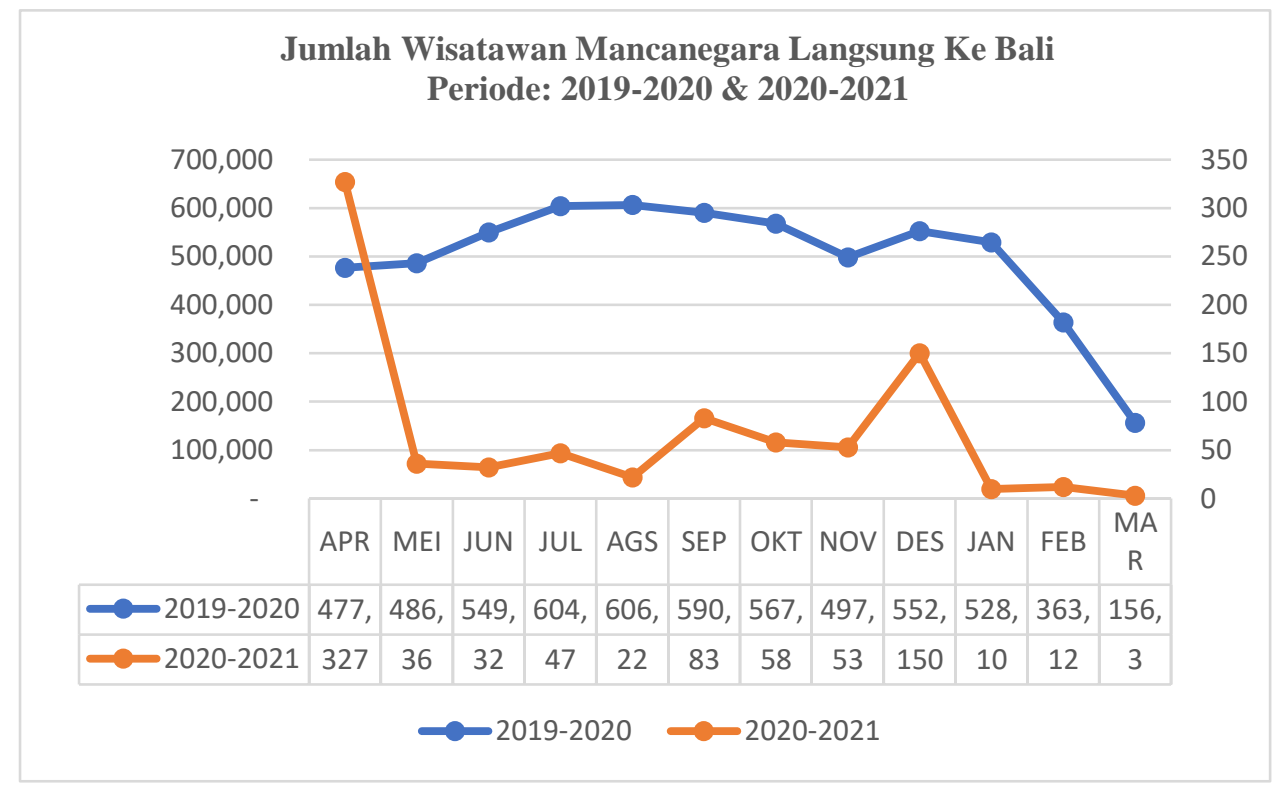

Gambar 1: Jumlah Wisatawan Mancanegara Langsung Ke Bali

Periode April 2019 - Maret 2020 dan April 2020 - Maret 2021

Sumber: Badan Pusat Statistik Provinsi Bali

Sektor pariwisata yang terpuruk akibat pandemi Covid-19 kini tengah memasuki tatanan kehidupan era baru. Demikian juga tren pariwisata telah berubah, dikarenakan pariwisata global tengah berjuang bersama-sama untuk bisa pulih kembali dari Covid-19. Para pelaku industri pariwisata harus menyadari perubahan yang menghadirkan kebijakan-kebijakan baru dari pemerintah dan munculnya kesadaran terkait pentingnya standar global dalam pelayanan permintaan dan perilaku wisatawan. Perubahan paradigma tengah berlangsung dan sejumlah protokol baru diterapkan untuk menyambut kondisi kenormalan baru di industri pariwisata.

Kriteria mutlak protokol tatanan kehidupan era baru disebutkan oleh Dinas Pariwisata Provinsi Bali, yang harus dipenuhi untuk pengajuan verifikasi dan mendapatkan sertifikat tatanan kehidupan era baru adalah aspek produk, pelayanan dan pengelolaan. Penelitian dilakukan terhadap ketiga aspek tersebut, termasuk unsur-unsur didalamnya 


\section{Aspek Produk}

Usaha perjalanan wisata harus melakukan asesmen mandiri menuju tatanan kehidupan era baru pada aspek produk yang mencakup pemenuhan terhadap tujuh unsur di bawah ini.

1. Tersedia tempat mencuci tangan dengan perlengkapannya di tempat usaha dengan jarak yang memadai. Kriteria pemenuhan unsur pada, ketersediaan:

a. Wastafel dengan keran air mengalir,

b. Sabun cuci tangan,

c. Tempat tisu atau pengering tangan,

d. Tempat sampah tertutup.

2. Tersedia tanda penunjuk arah lokasi tempat mencuci tangan dan hand sanitizer di tempat-tempat yang mudah dilihat. Kriteria pemenuhan unsur pada, ketersediaan tanda penunjuk arah lokasi mencuci tangan dalam bentuk poster atau spanduk atau signed yang mudah dilihat.

3. Tersedia hand sanitizer minimal di pintu masuk dan keluar. Kriteria pemenuhan unsur pada, ketertersediaan hand sanitizer dalam bentuk gel atau cair.

4. Tersedia alat pengukur suhu tubuh (thermo gun/thermo scanner) dengan jumlah yang disesuaikan dengan kapasitas karyawan. Kriteria pemenuhan unsur yaitu, ketersediaan alat pengukur suhu tubuh dengan sistem infrared atau digital.

5. Tersedia masker bagi pengunjung/wisatawan diberikan secara gratis atau berbayar. Kriteria pemenuhan unsur pada, ketersediaan masker atau face shield yang sesuai dengan standar protokol.

6. Tersedia papan informasi himbauan protokol kesehatan. Kriteria pemenuhan pada, ketersediaan poster atau spanduk atau signed informasi mengenai Covid 19 di area publik dan area karyawan.

7. Tersedianya sarana pembayaran nontunai. Kriteria pemenuhan unsur pada, ketersediaan mesin electronic data capture (EDC) atau metode pembayaran online lainnya.

Penelitian dilakukan terhadap aspek produk melalui pengecekan terhadap pelaksanaan pada ketujuh unsur didalamnya. Aspek produk merupakan salah satu dari tiga aspek yang harus dipenuhi, guna proses verifikasi dan pemberian sertifikat. Hasil observasi seperti tampak pada Tabel 1 yang menunjukkan usaha perjalanan wisata dengan kategori memenuhi $(\mathrm{M})$ dan belum memenuhi (BM) terhadap unsur-unsur dalam aspek produk. 
Tabel 1. Pemenuhan Kriteria Aspek Produk

\begin{tabular}{lllccccccc}
\hline & & \multicolumn{1}{c}{ Aspek Produk } \\
No & Usaha Perjalanan Wisata & \multicolumn{8}{c}{ Unsur Pemenuhan : } \\
& & 1 & 2 & 3 & 4 & 5 & 6 & 7 \\
\hline 1 & Alliance Indonesia & M & M & M & M & M & M & M \\
2 & Bali Lovindo Wisata & M & M & M & BM & M & M & M \\
3 & Ceria Tours \& Travel & BM & BM & BM & BM & BM & BM & M \\
4 & Golden Kris Tours & M & M & M & M & M & M & M \\
5 & Ravada Bali Tour & BM & BM & BM & BM & BM & BM & M \\
6 & Wahyu Mandiri & BM & BM & BM & BM & BM & BM & M \\
\hline
\end{tabular}

Berdasarkan Tabel 1, dua perusahaan usaha perjalanan wisata, yaitu Golden Kris Tours dan Alliance Indonesia telah memenuhi tujuh unsur pada aspek produk. Perusahaan Bali Lovindo Wisata harus memenuhi satu unsur aspek produk. Perusahaan Ceria Tours \& Travel, Ravada Bali Tour dan Wahyu Mandiri harus memenuhi enam unsur aspek produk. Perusahaan yang masuk kategori BM pada unsur aspek produk, merasa kesulitan untuk memenuhi kelengkapan yang dibutuhkan untuk protokol kesehatan. Belum adanya kegiatan pariwisata yang ditangani dan biaya yang diperlukan menjadi alasan perusahaan tidak melengkapi aspek produk. Unsur pemenuhan alat pengukur suhu tubuh dengan sistem infra red atau digital adalah kelengkapan protokol kesehatan yang dirasakan paling berat untuk dipenuhi, mengingat situasi pariwisata yang sedang terpuruk.

\section{Aspek Pelayanan}

Usaha perjalanan wisata harus melakukan asesmen mandiri menuju tatanan kehidupan era baru pada aspek pelayanan yang mencakup pemenuhan terhadap tiga unsur di bawah ini.

1. Melakukan pemeriksaan suhu tubuh kepada pengunjung/wisatawan dengan Thermo Gun/Thermo Scanner, dan jika terdeteksi suhu mencapai 37,30C atau lebih, maka pengunjung/wisatawan yang bersangkutan dilarang memasuki area event dan /atau berkoordinasi dengan pihak terkait untuk mendapat penanganan lebih lanjut. Kriteria pemenuhan unsur pada:

a. Ketersediaan standard operating procedure (SOP) untuk pengecekan atau pemeriksaan suhu tubuh pengunjung/wisatawan dan diterapkan secara konsisten,

b. Standard operating procedure (SOP) penanganan pengunjung/ wisatawan yang terdeteksi memiliki suhu tubuh $37,30^{\circ} \mathrm{C}$ atau lebih, dan diterapkan secara konsisten.

2. Melakukan pembersihan dengan disinfektan terhadap semua peralatan, perlengkapan dan fasilitas yang di sentuh oleh karyawan dan pihak terkait sebelum dan sesudah digunakan atau setiap 4 jam sekal. Kriteria pemenuhan unsur pada, ketersediaan:

a. Jadwal pembersihan peralatan, perlengkapan dan fasilitas event, 
b. Standard operating procedure (SOP) pembersihan peralatan, perlengkapan serta fasilitas event dan diterapkan secara konsisten

c. Cairan disinfektan beserta perlengkapannya,

d. Alat pelindung diri khusus jika diperlukan.

3. Menghindari sentuhan fisik pada saat melakukan pelayanan kepada pengunjung/wisatawan. Kriteria pemenuhan unsur pada, ketersediaan:

a. Poster himbauan untuk tidak saling berjabat tangan

b. Standard operating procedure (SOP) untuk mengatur interaksi karyawan dan pengunjung/wisatawan dan diterapkan secara konsisten.

Penelitian dilakukan terhadap aspek pelayanan melalui pengecekan terhadap pelaksanaan pada ketiga unsur didalamnya. Aspek pelayanan merupakan salah satu dari tiga aspek yang harus dipenuhi, guna proses verifikasi dan pemberian sertifikat. Hasil observasi seperti tampak pada Tabel 2 yang menunjukkan usaha perjalanan wisata dengan kategori memenuhi $(\mathrm{M})$ dan belum memenuhi (BM) terhadap unsur-unsur dalam aspek pelayanan.

Tabel 2. Pemenuhan Kriteria Aspek Pelayanan

\begin{tabular}{|c|c|c|c|c|}
\hline \multirow[t]{2}{*}{ No } & \multirow[t]{2}{*}{ Usaha Perjalanan Wisata } & \multicolumn{3}{|c|}{$\begin{array}{l}\text { Aspek Pelayanan } \\
\text { Unsur Pemenuhan : }\end{array}$} \\
\hline & & 1 & 2 & 3 \\
\hline 1 & Alliance Indonesia & M & M & M \\
\hline 2 & Bali Lovindo Wisata & $\mathrm{BM}$ & $\mathrm{BM}$ & $\mathrm{BM}$ \\
\hline 3 & Ceria Tours \& Travel & $\mathrm{BM}$ & M & $\mathrm{BM}$ \\
\hline 4 & Golden Kris Tours & M & M & M \\
\hline 5 & Ravada Bali Tour & $\mathrm{BM}$ & M & $\mathrm{BM}$ \\
\hline 6 & Wahyu Mandiri & $\mathrm{BM}$ & $\mathrm{BM}$ & $\mathrm{BM}$ \\
\hline
\end{tabular}

Berdasarkan tabel 1.2, dua perusahaan usaha perjalanan wisata, yaitu Golden Kris Tours dan Alliance Indonesia telah memenuhi ketiga unsur dalam aspek pelayanan. Perusahaan Bali Lovindo Wisata dan Wahyu Mandiri belum memenuhi tiga unsur dalam aspek pelayanan. Perusahaan Ceria Tours \& Travel dan Ravada Bali Tour harus memenuhi satu unsur aspek pelayanan. Adanya pembatasan formasi tim kerja selama pandemi Covid-19, sehingga tidak bisa membuat persyaratan dalam unsur aspek pelayanan menjadi alasan perusahaan yang berada dalam kategori BM.

\section{Aspek Pengelolaan}

Usaha perjalanan wisata harus melakukan asesmen mandiri menuju tatanan kehidupan era baru pada aspek pengelolaan yang mencakup pemenuhan terhadap 11 unsur di bawah ini.

1. Memiliki sistem pengaturan interaksi dengan jarak minimal 1 meter. Kriteria pemenuhan unsur pada, ketersediaan:

a. Tanda pengaturan jarak berupa sticker atau poster himbauan 
b. Standard operating procedure (SOP) tentang pengaturan interaksi dan diterapkan secara konsisten.

2. Memiliki sistem pengaturan antrian dengan jarak minimal minimal 1 meter. Kriteria pemenuhan unsur pada, tersedia:

a. Tanda pengaturan jarak berupa sticker atau poster himbauan,

b. Standard operating procedure (SOP) tentang pengaturan interaksi dan diterapkan secara konsisten.

3. Memiliki sistem pengaturan tempat duduk dengan jarak minimal 1 meter. Kriteria pemenuhan unsur pada, ketersediaan:

a. Tanda pengaturan jarak tempat duduk berupa sticker atau poster himbauan,

b. Standard operating procedure (SOP) tentang pengaturan jarak tempat duduk yang diterapkan secara konsisten.

4. Memiliki sistem pengaturan kerumunan dengan jarak minimal 1 meter. Kriteria pemenuhan unsur pada, ketersediaan:

a. Tanda pengaturan kapasitas berupa sticker atau poster,

b. Standard operating procedure (SOP) tentang pengaturan kerumunan dan diterapkan secara konsisten.

5. Menetapkan jam operasional sesuai dengan kebijakan yang ditetapkan Pemerintah Daerah setempat sesuai ketentuan peraturan perundang-undangan. Kriteria pemenuhan unsur pada, ketersediaan:

a. Tanda jam operasional berupa, sticker atau poster,

b. Standard operating procedure (SOP) tentang pengaturan jam operasional dan diterapkan secara konsisten.

6. Menyediakan pelatihan terhadap karyawan untuk penerapan protokol kesehatan. Kriteria pemenuhan unsur pada, ketersediaan jadwal pelatihan kusus penanganan Covid-19 yang di lakukan secara berkala oleh pihak manajemen kepada karyawan.

7. Membentuk petugas khusus pemantau Protokol tatanan kehidupan era baru. Kriteria pemenuhan unsur pada, ketersediaan bagan tim pemantau protokol tatanan kehidupan era baru beserta uraian tugas masing - masing.

8. Menyiapkan sistem penanganan kasus emergency. Kriteria pemenuhan unsur pada, ketersediaan:

a. Standard operating procedure (SOP) khusus penanganan Covid-19 dan diterapkan secara konsisten,

b. Jalur evakuasi kusus penanganan kasus Covid-19,

c. Ruang isolasi khusus,

d. Alat pelindung diri (APD) yang sesuai dengan standar protokol Covid-19,

e. Kontrak kerjasama dengan klinik atau rumah sakit yang menangani kasus Covid-19. 
9. Mengatur protokol kesehatan antara lain etika meludah, batuk, dan bersin. Kriteria pemenuhan unsur pada, ketersediaan penanda himbauan untuk etika meludah, batuk dan bersin berupa sticker atau poster.

10. Untuk MICE: Menetapkan jumlah tamu/peserta yang dapat menghadiri langsung pertemuan/event sesuai kapasitas venue.

11. Memiliki dan menerapkan protokol tatanan kehidupan era baru pada standard operating procedure (SOP):

a. Protokol kesehatan (CHSE),

b. Penggunaan busana adat Bali,

c. Penggunaan aksara Bali,

d. Pembatasan timbulan sampah plastik,

e. Pemanfaatan produk lokal Bali.

Kriteria pemenuhan unsur pada, ketersediaan:

a. Standard operating procedure (SOP) yang sesuai dengan protokol kesehatan,

b. Standard operating procedure (SOP) penggunaan busana adat Bali yang tetap mengacu ke protokol kesehatan,

c. Standard operating procedure (SOP) penggunaan aksara Bali tentang protokol kesehatan,

d. Standard operating procedure (SOP) tentang pembatasan timbulan sampah yang sesuai dengan protokol kesehatan,

e. Standard operating procedure (SOP) tentang pemanfaatan produk lokal Bali.

Penelitian dilakukan terhadap aspek pengelolaan melalui pengecekan terhadap pelaksanaan pada 11 unsur didalamnya. Aspek pengelolaan merupakan salah satu dari tiga aspek yang harus dipenuhi, guna proses verifikasi dan pemberian sertifikat. Hasil observasi seperti tampak pada Tabel 3 yang menunjukkan usaha perjalanan wisata dengan kategori memenuhi (M) dan belum memenuhi (BM) terhadap unsur-unsur dalam aspek pengelolaan.

Tabel 3. Pemenuhan Kriteria Aspek Pengelolaan

\begin{tabular}{|c|c|c|c|c|c|c|c|c|c|c|c|c|}
\hline \multirow{3}{*}{ No } & \multirow{3}{*}{ Usaha Perjalanan Wisata } & \multicolumn{11}{|c|}{ Aspek Pengelolaan } \\
\hline & & \multicolumn{11}{|c|}{ Unsur Pemenuhan : } \\
\hline & & 1 & 2 & 3 & 4 & 5 & 6 & 7 & 8 & 9 & 10 & 11 \\
\hline 1 & Alliance Indonesia & M & M & M & M & M & M & M & M & M & M & M \\
\hline 4 & Bali Lovindo & BM & $\mathrm{BM}$ & BM & $\mathrm{BM}$ & $\mathrm{BM}$ & $\mathrm{BM}$ & $\mathrm{BM}$ & BM & $\mathrm{BM}$ & BM & BM \\
\hline 9 & Ceria Tours & $\mathrm{BM}$ & $\mathrm{BM}$ & $\mathrm{BM}$ & $\mathrm{BM}$ & $\mathrm{BM}$ & $\mathrm{BM}$ & $\mathrm{BM}$ & BM & $\mathrm{BM}$ & $\mathrm{BM}$ & $\mathrm{BM}$ \\
\hline 11 & Golden Kris & M & M & M & M & M & M & M & M & M & M & M \\
\hline 19 & Ravada Bali & $\mathrm{BM}$ & $\mathrm{BM}$ & $\mathrm{BM}$ & $\mathrm{BM}$ & $\mathrm{BM}$ & $\mathrm{BM}$ & $\mathrm{BM}$ & $\mathrm{BM}$ & $\mathrm{BM}$ & $\mathrm{BM}$ & $\mathrm{BM}$ \\
\hline 25 & Wahyu Mandiri & BM & $\mathrm{BM}$ & BM & $\mathrm{BM}$ & $\mathrm{BM}$ & $\mathrm{BM}$ & BM & BM & $\mathrm{BM}$ & BM & $\mathrm{BM}$ \\
\hline
\end{tabular}


Berdasarkan tabel 1.3, dua perusahaan usaha perjalanan wisata, yaitu Golden Kris Tours dan Alliance Indonesia telah memenuhi sebelas unsur dalam aspek pengelolaan. Perusahaan Bali Lovindo Wisata, Ceria Tours \& Travel, Ravada Bali dan Wahyu Mandiri belum memenuhi sebelas unsur dalam aspek pengelolaan. Kondisi perusahaan dalam masa pandemi Covid-19, seperti pembatasan formasi tim kerja tidak lengkap karena sebagian besar karyawan dirumahkan, pembatasan jam kerja bagi karyawan yang masih aktif bekerja dan tidak ada kegiatan pariwisata merupakan alasan perusahaan dalam kategori BM.

\section{SIMPULAN}

Berbagai kendala yang dihadapi usaha perjalanan wisata terhadap pemenuhan asesmen mandiri menunjukan ketidaksiapan pelaksanaan tatanan kehidupan era baru di masa pandemi Covid-19. Dua perusahaan usaha perjalanan wisata bisa melanjutkan pengajuan verifikasi untuk memperoleh sertifikat tatanan kehidupan era baru, namun empat perusahaan harus memenuhi unsur-unsur dalam kategori BM sebelum proses selanjutnya. Perusahaan harus memanfaatkan momentum pandemi Covid-19 ini untuk memenuhi unsur-unsur dalam aspek produk, pelayanan dan pengelolaan. Hal ini penting guna memastikan wisatawan menerima layanan yang berkualitas. Hospitality industry pada usaha perjalanan wisata bisa kembali normal melalui komitmen seluruh pihak (teamwork) yang terlibat di dalamnya dalam menciptakan tempat kerja yang aman, nyaman dan sehat. Upaya menerapkan protokol kesehatan menjadi jaminan utama bagi wisatawan mancanegara mengunjungi Pulau Bali sebagai destinasi utama Indonesia memasuki era tatanan kehidupan baru.

\section{DAFTAR RUJUKAN}

Anggito, Albi \& Johan Setiawan. 2018. Metodologi Penelitian Kualitatif. Jawa Barat: CV. Jejak.

Bafadhal, Aniesta Samira. 2018. Perencanaan Bisnis Pariwisata (Pendekatan Lean Planning). Malang: UB Press.

Gupta, I.G.B. dan Nelsye Lumanauw. 2021. Protokol Tatanan Kehidupan Era Baru Di Destinasi Pariwisata Nusa Dua. Jurnal Manajemen dan Bisinis Equilibrium. Vol 7. No 1. (2021), hal. 72-88. E-ISSN: 2723-1704 P-ISSN: 2443-3934. DOI: https://doi.org/10.47329/jurnal_mbe.v7i1.535

Lumanauw, N. 2020. Perencanaan Paket Wisata Pada Biro Perjalanan Wisata (Inbound (Studi Kasus Di PT. Golden Kris Tours, Bali). Jurnal Ilmiah Hospitality, 9(1), pp. 19-30. doi: 10.47492/jih.v9i1.26.

Paramita, I.B.G. dan I Gede Gita Purnama Arsa Putra. 2020. New Normal Bagi Pariwisata Bali Di Masa Pandemi Covid 19. Pariwisata Budaya: Jurnal Ilmiah Pariwisata Agama Dan Budaya. ISSN 2527-9734. EISSN 2614-5340

Putra, A.C. 2020. Seri 3 Covid-19 \& New Normal Informasi yang Harus Diketahui Seputar Coronavirus. Indonesia: Guepedia. 
Rahmasari, A. dkk. (Ed). 2019. Prosiding Temu Ilmiah Nasional Balitbang Tahun 2019 "Percepatan Pengembangan Desa Mandiri". Jawa Timur: Badan Penelitian dan Pengembangan, Provinsi Jawa Timur

\section{Peraturan:}

Keputusan Menteri Kesehatan Republik Indonesia Nomor HK.01.07/Menkes/328/2020 Tentang Panduan Pencegaharan Dan Pengendalian Corona Virus Desease 2019 Covid-19) Di Tempat Kerja Perkantoran Dan Industri Dalam Mendukung Keberlangsungan Usaha Pada Situasi Pandemi.

Keputusan Edaran Menteri Kesehatan Nomor : HK.01.07/Menkes/382/2020 tentang protokol kesehatan bagi masyarakat di tempat dan fasilitas umum dalam rangka pencegahan dan pengendalian corona virus disease 2019 (Covid-19)

Petunjuk Teknis Penerbitan Sertifikat Tatanan Era Baru Bidang Pariwisata. https://disparda.baliprov.go.id/wp-content/uploads/2020/07/Juknis-Verifikasi-Rev.2-Juli-2020-1.pdf. Diunduh tanggal 2 November 2021

Surat Edaran Gubernur Bali Nomor : 355/03-L/HK/2020, tanggal 2 Juli 2020, tentang Pembentukan dan Susunan Keanggotaan Tim Verifikasi Prokotol Tatanan Kehidupan Era Baru Bidang Pariwisata.

Peraturan Walikota Denpasar No 48 Tahun 2020 tentang Penerapan Disiplin dan Penegakan Hukum Protokol Kesehatan Sebagai Upaya Pencegahan dan Pengendalian Corona Virus Disease 2019 dalam Tatanan Kehidupan Era Baru.

\section{Internet:}

Badan Pusat Statistik Provinsi Bali. https://bali.bps.go.id/indicator/16/106/1/banyaknyawisatawan-mancanegara-bulanan-ke-bali-menurut-pintu-masuk.html diunduh tanggal 10 November 2021.

Dinas Pariwisata https://disparda.baliprov.go.id/category/veriikasi/verifikasi-veriikasi/ diunduh tanggal 10 November 2021 